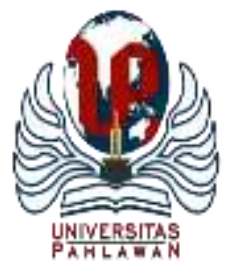

Edukatif : Jurnal Ilmu Pendidikan Volume 3 Nomor 6 Tahun 2021 Halm 5231 - 5239

EDUKATIF: JURNAL ILMU PENDIDIKAN

Research \& Learning in Education

https:/ledukatif.org/index.php/edukatif/index

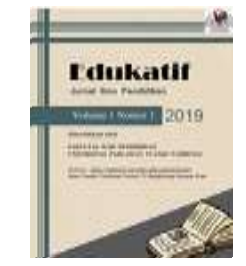

\title{
Pengaruh Digitalisasi Pelayanan Publik terhadap Kinerja Pegawai pada Masa Pandemi di Lembaga Pendidikan dan Pelatihan
}

\author{
Anita Ilyas $^{1 凶}$, Bahagia $^{2}$ \\ Puslatbang PKASN LAN, Indonesia ${ }^{1}$ \\ Universitas Ibn Khaldun Bogor, Indonesia ${ }^{2}$ \\ E-mail : anitailyas64@gmail.com ${ }^{1}$, bahagiagia59@ yahoo.co.id ${ }^{2}$
}

\begin{abstract}
Abstrak
Tujuan penelitian ini adalah untuk mengetahui seberapa besar pengaruh proses digitalisasi dan input digitalisasi pelayanan publik terhadap kinerja pegawai di masa pandemi. Revolusi industri 4.0 dan pandemi covid 19 menjadikan pemanfaatan teknologi informasi sebuah keharusan, agar pelaksanaan pekerjaan dan pelayanan publik dapat tetap berjalan. Metode yang digunakan dalam penelitian ini mengabungan analisis regresi dan analisis deskriptif. Variabel independent (Y) dalam penelitian adalah kinerja pegawai yang meliputi ketepatan target, kualitas hasil, kecepatan dan keakuratan. Variabel terikatnya terdiri dari 2 variabel yakni Proses Digitalisasi $\left(\mathrm{X}_{1}\right)$ yaitu perencanaan, pengorganisasian, pelaksanaan dan monitoring dan evaluasi. Variabel berikutnya adalah input digitalisasi $\left(\mathrm{X}_{2}\right)$ yaitu SDM, anggaran dan sarana prasarana. Hasil analisis regresi menujukan bahwa variable proses digitalisasi dan variable input digitalisasi berpengaruh secara signifikan terhadap kinerja pegawai dengan koefisien determinasi atau $\mathrm{R}^{2}$ 0,98. Artinya proses digitalisasi dengan teknologi masa kini dan input yang kompeten berpengaruh $98 \%$ terhadap kinerja pegawai maupun kinerja organisasi. Hasil analisis deskriptif menunjukan bahwa yang perlu ditingkatkan dalam menciptakan transformasi pelayanan publik digita komponen yang harus diperhatikan adalah apresiasi pimpinan, anggaran, jumlah dan kapasitas sumber daya manusia.
\end{abstract}

Kata Kunci: Digitalisasi, Kinerja, Lembaga Pendidikan dan Pelatihan

\section{Abstract}

The purpose of this study was to determine how much influence the process of digitizing public services and the input of digitizing public services had on employee performance during the pandemic. The industrial revolution 4.0 and the COVID-19 pandemic make the use of information technology (ICT) a must, so that the implementation of work and public services can continue. The method used in this study combines regression analysis and descriptive analysis. The independent variable $(Y)$ in the study is employee performance which includes target accuracy, quality of results, speed and accuracy. The dependent variable consists of 2 variables, namely the Digitization Process (X1), namely planning, organizing, implementing and monitoring and evaluating. The next variable is the input of digitization (X2), namely human resources, budget and infrastructure. The results of the regression analysis show that the digitization process variable and the digitization input variable have a significant effect on employee performance with a coefficient of determination or $R 2$ of 0.98 . This means that the digitization process with today's technology and competent input has an effect of $98 \%$ on employee performance and organizational performance. The results of the analysis show that what needs to be improved in creating a digital service transformation, the components that must be considered are the appreciation of the leadership, budget, number, and capacity of human resources.

Keywords: Digitization, Performance, Educational and Training Institutions

Copyright (c) 2021 Anita Ilyas, Bahagia

$\triangle$ Corresponding author:

Email : anitailyas64@gmail.com

DOI : https://doi.org/10.31004/edukatif.v3i6.1173

ISSN 2656-8063 (Media Cetak)

ISSN 2656-8071 (Media Online)

Edukatif : Jurnal Ilmu Pendidikan Vol 3 No 6 Tahun 2021 p-ISSN 2656-8063 e-ISSN 2656-8071 
5232 Pengaruh Digitalisasi Pelayanan Publik terhadap Kinerja Pegawai pada Masa Pandemi di Lembaga Pendidikan dan Pelatihan - Anita Ilyas, Bahagia

DOI: https://doi.org/10.31004/edukatif.v3i6.1173

\section{PENDAHULUAN}

Saat ini, akses pada teknologi informasi dan komunikasi (TIK) memainkan peran penting dalam pembangunan ekonomi, sosial, budaya, pendidikan dan bidang lainnya. Penyebaran virus covid 19 yang menyebabkan pandemi di Indonesia semakin memerkuat bahwa teknologi informasi (ICT) menjadi sebuah kebutuhan dan solusi terhadap penyelesaian permasalahan yang ditimbulkan karena penyebaran virus covid19 bagi oganisasi pemerintah maupun organisasi bisnis. Teknologi memberikan efek kombinatorial yang mempercepat kemajuan diberbagai aspek baik dibidang bisnis maupun kehidupan bermasyarakat secara eksponensial (Royyana, 2018). Setiap teknologi dicipatakan untuk mempermudah dan mendukung kegiatan manusia (Mukhsin, 2020). Teknologi informasi dewasa ini menjadi hal yang sangat penting karena sudah banyak organisasi pemerintah yang menerapkan teknologi informasi untuk mendukung kegiatan organisasi. Penerapan teknologi informasi pada organisasi pemerintah tentunya memiliki tujuan yang berbeda karena penerapan TI pada suatu organisasi adalah untuk mendukung kepentingan organisasinya (Yohanes et.al, 2013). Bahkan perkembangan teknologi pada akhirnya dapat mengubah cara pandang, perilaku, sifat dengan mengadopsi perubahan teknologi ( Santoso et al., 2020).

Informasi dan teknologi informasi sudah berkembang di masyarakat dan sulit untuk memikirkan masalah publik atau layanan pemerintah yang tidak tidak menggunakan teknologi informasi (Gil-Garcia et al., 2018). Mengingat pesatnya pertumbuhan teknologi, banyak pemerintah telah mengadopsinya untuk mendefinisikan kembali cara pemerintah berinteraksi dengan warganya (Warf, 2014). Perubahan cara kerja pemerintah dengan mentransformasikan cara kerja komputer dan teknologi informasi, dimana konektivitas, efisiensi, tranparansi, dan berbagi informasi menjadi prinsip dasar pemerintahan supaya terkoneksi (Harimurti, 2010). Di Indonesia untuk merespon perkembangan teknologi informasi atau revolusi industry 4.0 pemerintah mengeluarkan kebijakan melalui Peraturan Presiden Nomor 95 tahun 2018 tentang Sistem Pemerintahan Berbasis Elektronik (SPBE) yang bertujuan untuk mewujudkan tata kelola pemerintahan yang bersih, efektif, transparan, dan akuntabel serta pelayanan publik yang berkualitas dan terpercaya. Jauh sebelum kebijakan sistem pemerintahan berbasis elektronik muncul, pemerintah juga sudah mengeluarkan kebijakan $e$ Government melalui Instruksi Presiden No 23 tahun 2003 tentang kebijakan dan strategi nasional pengembangan e-Government Indonesia. Upaya pemerintah dalam meningkatan pelayanan publik melalui pendekatan teknologi informasi tentu merupakan sebuah terobosan yang sangat diperlukan. Penciptaan nilai publik dengan pendekatan teknologi informasi akan menciptakan efektifitas dan efisiensi terlebih dalam pelaksanaan revolusi industri 4.0 dan mengatasi permasalahan pandemi covid-19.

Penciptaan nilai publik semakin dipandang sebagai poros utama transformasi digital pemerintah (Roy, 2019). Pengembangan e-government merupakan salah satu bentuk upaya pemerintah untuk menciptakan lingkungan birokrasi yang terbuka, bersih dan akuntabel dengan memanfaatkan teknologi informasi (Fadhlurrahman et al., 2018). Proses penerapan e-government melalui beberapa tahapan yaitu kehadiran (web presence), interaksi (interaction), transaksi (transaction), dan transformasi (transformation) (Bona et al., 2021). E-Government sebagai suatu mekanisme baru dalam interaksi antara pemerintah dan masyarakat, dalam pemanfaatan teknologi informasi terutama internet harus dapat memperbaiki layanan kepada masyarakat (oke 3). Peningkatan pelayanan publik (public service) harus mendapatkan perhatian utama dari pemerintah, karena pelayanan publik merupakan hak-hak sosial dasar dari masyarakat (social rihgts) ataupun fundamental rights) (Holle, 2011). Penciptaan nilai publik semakin dipandang sebagai prisma sentral transformasi digital pemerintah (Bannister \& Connolly, 2014;(Pang et al., 2014). Penyelenggaraan pemerintahan yang baik pada dasarnya menuntut keterlibatan seluruh komponen pemangku kepentingan baik birokrasi itu sendiri, swasta dan masyarakat (Yudhi Supridi, 2015). Transformasi pelayanan publik melalui proses digitalisasi akan berpengaruh terhadap kinerja individu maupun organisasi. Sebagai salah satu fungsi utama pemerintah maka pelayanan tersebut sudah seharusnya dapat diselenggarakan secara berkualitas oleh pemerintah. Kualitas 
pelayanan merupakan tingkat keunggulan yang diharapkan dan pengendalian atas tingkat keunggulan tersebut untuk memenuhi keinginan pelanggan.

Apabila jasa atau pelayanan yang diterima atau dirasakan (perceived service) sesuai dengan yang diharapkan, maka kualitas jasa atau pelayanan dipersepsikan baik dan memuaskan (Yani, 2016). Penerapan $e$ Government berpengaruh negatif terhadap probabilitas terjadinya praktik korupsi di pemerintah daerah, Indonesia (Maria \& Halim, 2021). Hal ini mewujudkan praktik pemerintahan yang lebih efisien dan efektif dalam proses pelaksanaan pelayanan publik, agar lebih terjangkau dan memperluas akses publik untuk memperoleh informasi, sehingga terciptanya asas akuntabilitas, transparansi dan partisipasi publik yang tinggi terhadap pemerintahan (Rahmaini, 2021). Implementasi atau manifestasi dari good 5 governance itu, dalam paradigma yang telah berubah ini, pada dasarnya adalah menjadi tuntutan bagi pemerintah local yang secara langsung berinteraksi dengan masyarakat dalam rangka penataan pemerintahan dan pelayanan public yang lebih baik (Astuti, 2005).

Revolusi industri 4.0 dan pandemi covid-19 memaksa setiap orang maupun organisasi untuk menggunakan teknologi dalam berbagai aktivitasnya. Hal ini dilakukan sebagai upaya meminimalisir penyebaran covid 19 namun semua aktivitas pekerjaan tetap dapat dilakukan. Caranya adalah melalui penggunaan teknologi informasi sehingga kualitas pelayanan publik yang baik dapat tetap diwujudkan dan didelivery. Meskipun demikian terdapat kendala penerapan e-government adalah aspek teknologi adalah koneksi internet yang sangat lambat, dengan tidak adanya saran dan prasarana yang memadai untuk menerapkan Egovernment di wilayah tersebut. Budaya dari pengguna juga menjadi faktor hambatan dalam penerapan Egovernment di suatu daerah (Musfikar, 2018). Penelitian ini bertujuan untuk menganalisis seberapa besar pengaruh digitalisasi dalam pelayanan publik terhadap kinerja pegawai di saat terjadi pandemi covid 19 dan berjalannya proses revolusi industri melalui digitalisasi pada organisasi pemerintah .

\section{METODE PENELITIAN}

Metode penelitian yang digunakan dalam penelitian ini adalah metode regresi linier berganda. Uji regresi digunakan untuk mengukur seberapa besar pengaruh variabel bebas terhadap variable terikat. Uji Regresi linier berganda adalah uji regresi untuk menganalisis hubungan dan pengaruh variable bebas yang berjumlah lebih dari satu variable bebas (Widarjono, 2007:63). Sampel yang digunakan dalam penelitian ini berjumlah 69 responden yang digali informasinya melalui penyebaran kuisioner dengan pertanyaan tertutup dan pertanyaan terbuka. Model regresi sudah dipastikan memenuhi asumsi dengan tidak adanya multikolinieritas, heteroskedastisitas, dan autokorelasi. Sehingga model layak dan hasilnya dapat diinterpretasikan. Variabel yang digunakan dalam penelitian adalah variable kinerja pegawai, Y (yang meliputi ketepatan target, kualitas hasil, kecepatan dan keakuratan). Variabel terikatnya terdiri dari variable proses digitalisasi, $\mathrm{X}_{1}$ (perencanaan, pengorganisasian, pelaksanaan dan monitoring dan evaluasi), variabel input digitalisasi, $\mathrm{X}_{2}$ (sumber daya manusia, anggaran dan sarana prasarana).

\section{HASIL DAN PEMBAHASAN PENELITIAN}

\section{Pengaruh Input dan Proses Digitalisasi Terhadap Kinerja}

Hasil dari analisis regresi ditemukan bahwa proses digitalisasi yang dilakukan di lokus penelitian berdampak terhadap kinerja pegawai yang artinya juga berdampak terhadap kinerja organisasi. Hasil analisis regresi linier berganda menunjukan koefisien determinasi atau $\mathrm{R}^{2}$ dan adjust $\mathrm{R}^{2}$ sebesar 0.98 atau $98 \%$.

Tabel 1

Koefisien Determinasi

\begin{tabular}{cc}
\hline R Square & Adjust R Square \\
\hline 0,982 & 0,981 \\
\hline
\end{tabular}


Artinya bahwa variable proses digitalisasi, X1 yang terdiri dari perencanaan, pengorganisasian, pelaksanaan dan monitoring dan evaluasi, dan variabel input digitalisasi, X2 yang terdiri dari sumber daya manusia, anggaran dan sarana prasarana, berpengaruh signifikan terhadap variabel kinerja pegawai sebesar 98\%. Adapun besar koefisien setiap variabel dapat dilihat pada tabel koefisien beta berikut ini:

Tabel 2

Koefisien Beta

\begin{tabular}{cccc}
\hline Var. & $\mathrm{b}$ & $\mathrm{t}$ & Sig. \\
\hline Const & .711 & 2,036 & .046 \\
$\mathrm{X}_{1}$ & -.556 & $-4,267$ & .000 \\
$\mathrm{X}_{2}$ & .566 & 54,440 & .000 \\
\hline
\end{tabular}

Dari tabel di atas hasil mengujian secara simultan nilainya $0,00-0,04<$ dari 0,05 atau 5\%, sehingga dapat disimpulkan bahwa variabel input digitalisasi pelayanan publik dan proses digitalisasi pelayanan publik, secara bersama-sama berpengaruh terhadap kinerja.

Koefisien regresi $b_{1} X 1$ sebesar -0,556 yang artinya setiap penurunan dari variabel $X_{1}$ proses digitalisasi yaitu Perencanaan, Pengorganisasian, Pelaksanaan dan Monitoring dan Evaluasi maka akan menurunkan kinerja organisasi sebesar 0,556, sedangkan untuk koefisien beta $\mathrm{X}_{2}$ perencanaan digitalisasi yaitu SDM, Anggaran dan Sarana Prasarana nilai koefisiennya sebesar 0,566 yang artinya setiap kenaikan variabel perencanaan digitalisasi akan menaikan kinerja pegawai sebesar 0,566. Dari hasil uji regresi di atas menunjukan bahwa pengaruh dari perencanaan digitalisasi dan proses digitalisasi dalam pelayanan publik sangat berpengaruh terhadap kinerja pegawai dan kinerja organisasi. Transformasi digital menciptakan peluang bagi organisasi dalam meningkatkan efisiensi dan inovasi. Teknologi membuat pelayanan publik menjadi lebih cepat dan murah sehingga penerapan teknologi informasi dalam pelayan publik menjadi sebuah terobosan (Kudyba et al., 2020). Secara sosiologis, teknologi memiliki makna yang lebih mendalam daripada peralatan. Teknologi menetapkan suatu kerangka bagi kebudayaan non material suatu kelompok. Jika teknologi suatu kelompok mengalami perubahan, maka cara berpikir manusia juga akan mengalami perubahan. Hal ini juga berdampak pada cara mereka berhubungan dengan yang lain (Ngafifi, 2014)

\section{Proses Digitalisasi}

Indikator dari variabel proses digitalisasi adalah perencanaan, pengorganisasian, pelaksanaan, monitoring dan evaluasi. Adapun secara detail untuk variabel perencanaan kita dapat melihat dari indikatorindikator pada gambar berikut:

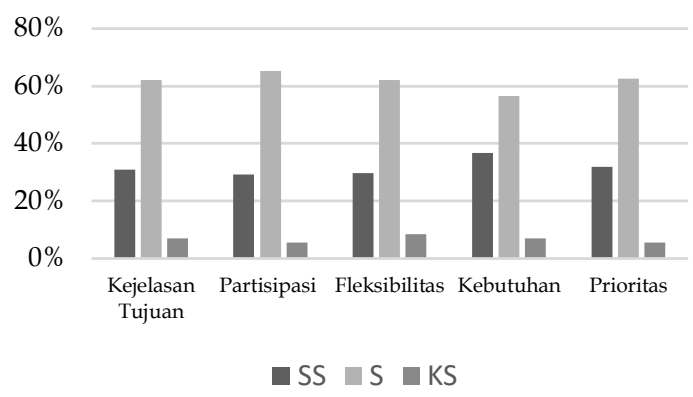

\section{Gambar 1. Indikator Perencanaan}

Pada gambar indikator perancanaan terlihat bahwa hasilnya ditemukan paling banyak responden setuju dan sangat setuju apabila digabung semua indicator menunjukan nilai 92-94\%. Artinya dalam merencanaan digitalisasi perlu ada kejelasan tujuan, partisipasi pihak- pihak terkait, fleksibilitas perencanaan, ada kesesuaian dengan kebutuhan dan adanya prioritas hasil pertimbangan dari berbagai prioritas. Semua indicator tersebut sudah dilakukan dengan baik pada lokus penelitian ini. Temuan ini sejalan dengan pernyataan Stone, (2019:53) bahwa perlu ada kejelasan dalam transformasi digital dengan tujuan dan sasaran organisasi, 
transformasi perlu dilakukan karena ada alasan- alasan organisasi atau kebutuhan organisasi, sehingga meminimalisir tidak berjaalannya tranformasi digital.

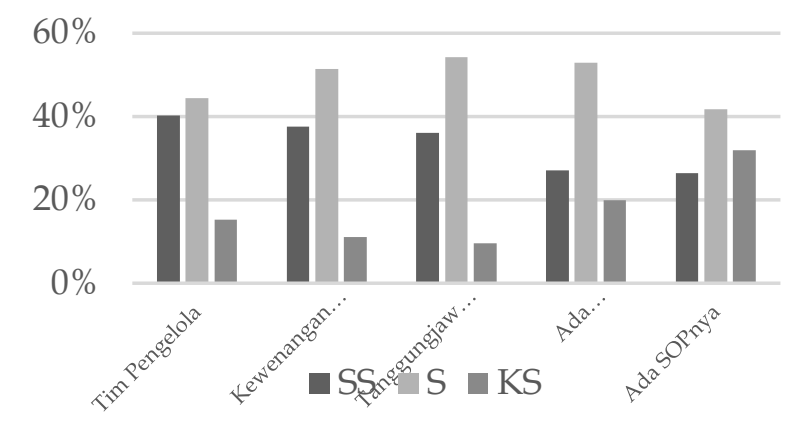

\section{Gambar 2. Indikator Pengorganisasian Digitalisasi}

Organisasi supaya bisa berjalan dengan baik perlu adanya struktur organisasi dan prosedur pelaksanaan pekerjaan. Pembagian tugas dan wewenang internal, dan system koordinasi dan komitmen individu pada doktrin dan program organisasi akan mempengaruhi kemampuan sumber daya organisasi untuk melaksanakan program-program kerja yang sudah ditetapkan (Maimunah, 2017). Bagaimana kami memisahkan tugas dan tanggung jawab ini di seluruh manajemen dan tim. Pada Gambar 2 di atas terlihat bahwa dalam pengorganisasian teknologi dan informasi (TIK) pelayanan publik dalam pengorganisasian harus memiliki tim pengelolanya, ada kewenangan, tim mampu bertanggung jawab terhadap tugas- tugas pengelolaan aplikasi teknologi, harus memiliki panduan bagi pengelola maupun penggunanya, serta adanya standar operasional prosedurnya.

Rata- rata responden setuju terhadap setiap indikator pengorganisasian tersebut. Nilai paling rendah adalah pada indikator standar operasional prosedur, sebesar 68,10\% artinya ada beberapa teknologi digital yang belum standar operasional prosedurnya. Setiap transformasi pasti akan ada dampak pada peran dan tanggung jawab dalam organisasinya masing-masing. Transformasi digital bukan pengecualian terhadap aturan. Transformasi dipengaruhi oleh teknologi digital. Transformasi digital terjadi karena adanya perubahan yang didorong oleh perkembangan teknologi pada organisasi dan lingkungan (Widnyani et al., 2021).

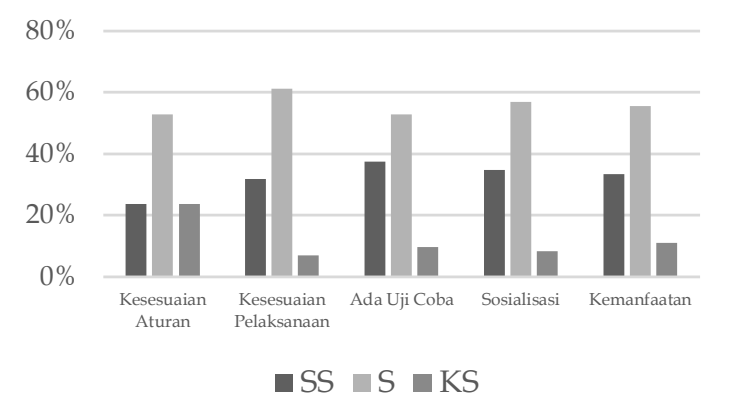

\section{Gambar 3. Indikator Pelaksanaan Digitalisasi}

Pada indikator pelaksanaan digitalisasi pelayanan publik (Gambar 3) kita bisa lihat bahwasanya yang yang tertinggi adalah adanya kesesuaian aatara rencana dengan pelaksanaan, apabila ditotal nilai responden sangat setuju dengan setuju sebesar $93 \%$, sosialaisasi $91,60 \%$, adanya uji coba $90 \%$, kemanfaatan $88.90 \%$, dan kesesuaian dengan aturan, $76,40 \%$. Dari data tersebut menunjukan bahwa untuk kesesuaian dengan aturan, proses digitalisasi di lokus penelitian masih perlu ditingkatkan lagi, sehingga ada kompatabilitas antara terobosan pelayanan publik melalui digitalisasi dengan aturan- aturan yang berlaku. Organisasi publik memiliki peran dan tanggung jawab yang telah ditentukan sebelumnya yang didasarkan pada hukum (Andrews et al., 2011). 
5236 Pengaruh Digitalisasi Pelayanan Publik terhadap Kinerja Pegawai pada Masa Pandemi di Lembaga Pendidikan dan Pelatihan - Anita Ilyas, Bahagia

DOI: https://doi.org/10.31004/edukatif.v3i6.1173

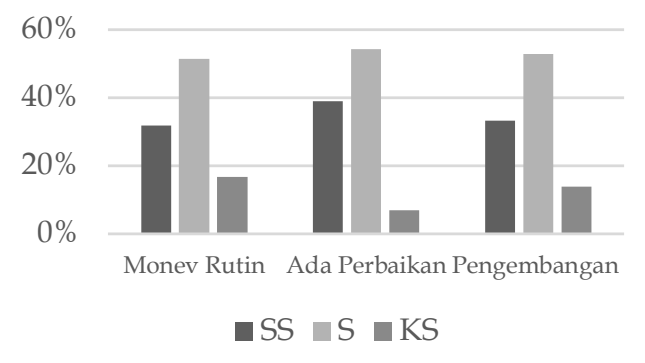

\section{Gambar 4. Indikator Monitoring dan Evaluasi}

Pada Gambar 4 untuk indikator monitoring, yang terpenting monev dilakukan dengan tujuan adanya perbaikan dengan nilai $93,10 \%$, yang berikutnya yang paling penting harus ada pengembangan dari proses digitalisasi sebagai bagian dari hasil monitoring dan evaluasi, 86,10\%. Monitoring dan evaluasi terhadap proses digitalisasi pelayanan publik di lokus penelitian dilakukan secara rutin, terlihat dari nilai gabungan setuju dan sangat setuju sebesar $83,30 \%$.

\section{Input Digitalisasi}

Variabel input digitalisasi dalam penelitian ini terdiri dari lima (5) indikator dengan rincian sebagaimana Gambar 5 berikut ini:

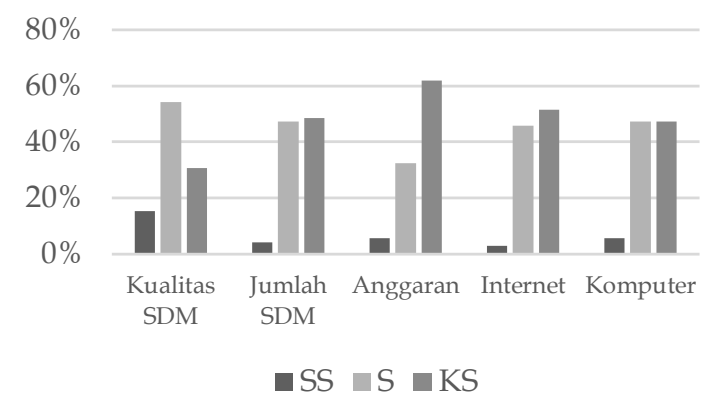

\section{Gambar 5. Indikator Input Digitalisasi}

Input digitalisasi di lokus penelitian dapat kita lihat pada gambar 5, input sumber daya manusia jumlah nilai gabungan setuju dan sangat setuju sebesar 69,50\%, jumlah SDM 51,40\%, Anggaran 38\%, kecepatan internet $48,60 \%$, komputer $52,80 \%$. Dari data tersebut kita dapat menyimpulkan bahwa input digitalisasi masih harus ditingkatkan lagi. Ditemukan bahwa kecepatan internet masih kurang kompatibel dengan aplikasi- aplikasi pelayanan publik yang ada sehingga kadang memunculkan kendala teknis baik bagi pengguna layanan maupun pemberi layanan yaitu pengelola aplikasi digital pelayanan publiknya. Anggaran yang dialokasinya pada lokus penelitian juga dianggap masih kurang apabila dibandingkan dengan jumlah kebutuhan aplikasi digital pelayanan publik. Yag berikutnya adalah kapasitas dan jumlah sumber daya manusia yang khsusus mengelola aplikasi digital masih terbatas baik kapasitas maupun jumlahnya.

\section{Kinerja Pegawai}

Kinerja pegawai sebagai dampak dari digitalisasi pelayanan publik, khususnya dimasa pandemi covid 19 dapat kita lihat pada gambar 6 berikut ini: 


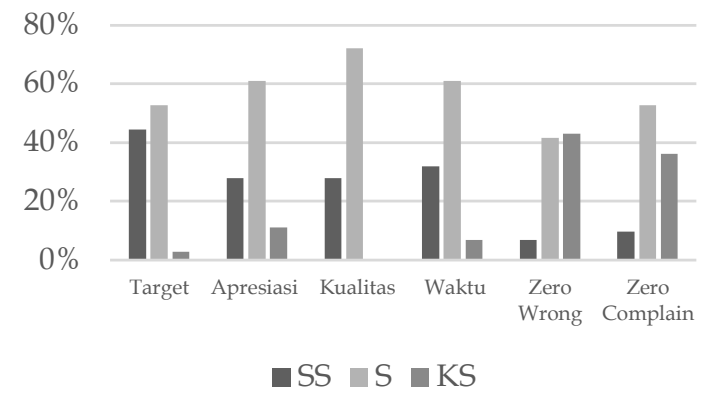

\section{Gambar 6. Indikator Kinerja Pegawai}

Kesesuan antara kinerja dengan target kinerja nilai gabungannya sebesar 97,20\%, artinya kinerja pegawai sudah sangat baik meskipun dilakukan dengan model berkerja work from home (WFH) maupun work from office (WFO). Artinya tidak ada masalah dengan perubahan pola kerja, sehingga proses digitalisasi pelayanan public dapat berjalan dengan efektif dan efisien. Indikator berikutnya adanya apresiasi dari pimpinan merupakan hal penting untuk memotivasi pegawai sehingga bisa meningkatkan atau mempertahankan kinerja, nilainya $88,90 \%$. Artinya apresiasi terhadap pegawai dengan kualitas kerja di masa pandemic harus mendapat apresiasi lebih, sehingga kinerja bisa tetap terjaga. Kualitas pekerjaan juga sudah bagus, hal ini sejalan dengan ketercapaian target sesuai dengan rencana dengan nilai $100 \%$. Namun demikian masih ditemukan kesalahan dan adanya komplen, meskipun bisa diperbaiki, masih peru ditingkatkan sehingga bisa mencapai nol kesalahan dalam pekerjaan.

\section{KESIMPULAN}

Proses digitalisasi yang terdiri dari perencanaan, pengorganisasian, pelaksanaan, monitoring dan evaluasi dan input digitalisasi yang terdiri dari kualistas dan jumlah sumber daya manusia (SDM), anggaran, kecepatan internet dan komputer, sangat berpengaruh terhadap kinerja pegawai dalam melaksanakan pekerjaan dan memberikan pelayanan publik. Temuan dalam penelitian ini agar pelayanan publik digital dapat lebih optimal lagi maka organisasi perlu meningkatkan anggaran, jumlah dan kapasitas sumber daya manusia, standar operasional prosedur. Untuk meningkatkan lagi kinerja pegawai manajemen perlu memberikan apresiasi pada pegawai, sebagai motivasi bagi pegawai karena dengan model kerja WFH dan WFO di masa pandemi berpengaruh besar terhadap kondisi psikologis pegawai. Harapannya dengan motivasi pegawai yang tinggi akan meningkatkan kualitas kerja sehingga meminalisir kesalahan kerja dan komplen pengguna layanan.

\section{DAFTAR PUSTAKA}

Andrews, R., Boyne, G. A., \& Walker, R. M. (2011). Dimensions of publicness and organizational performance: A review of the evidence. Journal of Public Administration Research and Theory, 21(SUPPL. 3). https://doi.org/10.1093/jopart/mur026

Astuti, S. Y. W. (2005). Peluang dan Tantangan Penerapan E-Governance Dalam Konteks Otonomi Daerah. Jurnal Universitas Airlangga, 1(1), 93-110.

Bannister, F., \& Connolly, R. (2014). ICT, public values and transformative government: A framework and programme for research. Government Information Quarterly, 31(1), 119-128.

https://doi.org/10.1016/j.giq.2013.06.002

Bona, D., Ayu, G., Intan, D., Ayu, I. D., \& Wirantari, P. (2021). Pendahuluan. 1, 13-19.

Fadhlurrahman, R., Saputra, M. C., \& Herlambang, A. D. (2018). Evaluasi Penerapan E-government Di Pemerintah Kota Batu Menggunakan Kerangka Kerja Pemeringkatan E-government Indonesia ( PeGI ). Jurnal Pengembangan Teknologi Informasi Dan Ilmu Komputer (J-PTIIK) Universitas Brawijaya, 
5238 Pengaruh Digitalisasi Pelayanan Publik terhadap Kinerja Pegawai pada Masa Pandemi di Lembaga Pendidikan dan Pelatihan - Anita Ilyas, Bahagia

DOI: https://doi.org/10.31004/edukatif.v3i6.1173

2(12), 5977-5982.

Gil-Garcia, J. R., Dawes, S. S., \& Pardo, T. A. (2018). Digital government and public management research: finding the crossroads. Public Management Review, 20(5), 633-646. https://doi.org/10.1080/14719037.2017.1327181

Harimurti, R. M. A. (2010). Dinamika Pengelolaan Teknologi Informasi Pemerintahan dan Model Connected Government Sebagai Solusi. Jurnal Penelitian Teknologi Dan Informasi, 1(2), 85-99. http://202.89.117.137/index.php/mti/article/view/7/7

Holle, E. S. (2011). Pelayanan Publik Melalui Electronic Government: Upaya Meminimalisir Praktek Maladministrasi Dalam Meningkatan Public Service. Sasi, 17(3), 21. https://doi.org/10.47268/sasi.v17i3.362

Kudyba, S., Fjermestad, J., \& Davenport, T. (2020). A research model for identifying factors that drive effective decision-making and the future of work. Journal of Intellectual Capital, 21(6), 835-851. https://doi.org/10.1108/JIC-05-2019-0130

Maimunah. (2017). Struktur Organisasi Diklat Online Dan Pengembangannya. Journal of Chemical Information and Modeling, 53(9), 21-25. http://www.elsevier.com/locate/scp

Maria, E., \& Halim, A. (2021). E-government dan Korupsi: Studi di Pemerintah Daerah, Indonesia dari Perspektif Teori Keagenan. EKUITAS (Jurnal Ekonomi Dan Keuangan), 5(1), 40-58. https://doi.org/10.24034/j25485024.y2021.v5.i1.4789

Mukhsin, M. (2020). Peranan Teknologi Informasi Dan Komunikasi Menerapkan Sistem Informasi Desa Dalam Publikasi Informasi Desa Di Era Globalisasi. Teknokom, 3(1), 7-15. https://doi.org/10.31943/teknokom.v3i1.43

Musfikar, R. (2018). Kendala Dalam Implementasi E-Government Pada Pemerintah Kabupaten Pidie. Cyberspace: Jurnal Pendidikan Teknologi Informasi, 2(1), 48. https://doi.org/10.22373/cs.v2i1.2746

Ngafifi, M. (2014). Kemajuan Teknologi Dan Pola Hidup Manusia Dalam Perspektif Sosial Budaya. Jurnal Pembangunan Pendidikan: Fondasi Dan Aplikasi, 2(1), 33-47.

https://doi.org/10.21831/jppfa.v2i1.2616

Pang, M. S., Lee, G., \& Delone, W. H. (2014). In public sector organisations: A public-value management perspective. Journal of Information Technology, 29(3), 187-205. https://doi.org/10.1057/jit.2014.2

Rahmaini, P. (2021). Penerapan Prinsip E-Government sebagai Wujud Inovasi Pelayanan Publik di Era Modern Tahun 2021. 1, 46-51.

Roy, J. P. (2019). Service, openness and engagement as digitally-based enablers of public value? A critical examination of digital government in Canada. International Journal of Public Administration in the Digital Age, 6(3), 23-40. https://doi.org/10.4018/IJPADA.2019070102

Royyana, A. (2018). Strategi Transformasi Digital Pada PT. Kimia Farma (PERSERO) TBK. Journal of Information Systems for Public Health, 3(3), 15-32.

Santoso, M. B., Irfan, M., \& Nurwati, N. (2020). Transformasi Praktik Pekerjaan Sosial Menuju Masyarakat 5.0. Sosio Informa, 6(2). https://doi.org/10.33007/inf.v6i2.2383

Warf, B. (2014). Asian geographies of e-government. Eurasian Geography and Economics, 55(1), 94-110. https://doi.org/10.1080/15387216.2014.941375

Widnyani, N. M., Luh, N., Surya, P., Christina, B., Putri, L., Internasional, U. B., Udayana, U., \& Kualitatif, P. (2021). Penerapan Transformasi Digital Pada Ukm Selama Pandemi. 6(1), $79-87$.

Yani, M. (2016). Pelaksanaan Tugas Kepada Camat Dalam Batu Ampar Kabupaten Kutai Timur. 4(1), 371382.

Yohanes et.al. (2013). The Implementation Strategy of Information Technology. Jurnal Tesis PMIS-UNTANPSIAN, 1-22. 
5239 Pengaruh Digitalisasi Pelayanan Publik terhadap Kinerja Pegawai pada Masa Pandemi di Lembaga Pendidikan dan Pelatihan - Anita Ilyas, Bahagia

DOI: https://doi.org/10.31004/edukatif.v3i6.1173

Yudhi Supridi. (2015). Pelaksanaan Good Governance (Tata Pemerintahan yang Baik) dalam Pelayanan Administrasi di Kantor Kecamatan Sambaliung Kabupaten Berau. EJournal Ilmu Pemerintahan, 3(1), 52-66. http://ejournal.ip.fisip-unmul.ac.id/site/wp-content/uploads/2015/02/e-journal Yudhi (02-04-1510-00-20).pdf 